\title{
NO TIME TO WASTE
}

Resilient waste management systems are needed to tackle future pandemic-like situations

Ronei de Almeida*

"School of Chemistry, Federal University of Rio de Janeiro. Av. Athos da Silveira Ramos 149, Ilha do Fundão, 21941-909, Rio de Janeiro, Brazil

${ }^{*}$ Corresponding author

*Address for correspondence: Ronei de Almeida, School of Chemistry, Federal University of Rio de Janeiro, UFRJ, Rio de Janeiro, Brazil. Av. Athos da Silveira Ramos 149, Ilha do Fundão, 21941-909, BI. I, laboratory I-124, Rio de Janeiro, Brazil. Phone and Fax: +55 21 2562-7346. E-mail: ronei@eq.ufri.br

Abstract: Solid waste management is a challenge in many countries, especially developing economies. The author identified nine major waste issues reported during the current pandemic period. The impacts of the pandemic continue to be felt and have indicated secondary impacts with respect the waste management. The reflective topics highlighted in the present article are not intended to be exhaustive. Still, they give us a starting point for reflecting on how we can construct a more resilient waste management system.

Keywords: policies, sustainability, waste management, waste sector

\section{Introduction}

Solid waste management is a challenge in many countries, especially developing economies (Batista et al., 2021). Coronavirus disease 2019 (COVID-19), caused by the severe acute respiratory syndrome coronavirus 2 (SARS-CoV-2), poses eco-environmental and public health threats. As we have seen during the COVID-19, the pandemic impacted several sectors, including the waste management system (Mofijur et al., 2021; Sarkodie \& Owusu, 2021). Within this context, the author identified nine major waste issues reported during the pandemic period in the relevant literature.

1) Pandemic has changed citizens' habits, bringing some waste generation behavioral trends and-new challenges. For instance, lockdown measures have led to an increase in the amount of packaging used for the delivery of food, 
online shopping, and household groceries (Ganguly \& Chakraborty, 2021; Kulkarni \& Anantharama, 2020; Liang et al., 2021).

2) The persistence of the SARS-CoV-2 on waste surfaces and materials has been reported in recent literature (Kampf et al., 2020). As a result, waste streams represent a route for viral transmission being a potential risk for the professionals involved in the waste chain (Di Maria et al., 2020). (Almeida et al., 2021 ) reported that coronavirus contamination among waste workers was up to 5.5-fold higher.

3) Biomedical waste generation increased, aligned with the increase in the number of confirmed COVID-19 cases (Agamuthu \& Barasarathi, 2020; Sangkham, 2020). If improperly collected or treated, contaminated wastes are a significant risk to medical staff and patients and can also accelerate disease spread (Ramteke \& Sahu, 2020; Yu et al., 2020).

4) The generation of an excessive amount of pandemic-related waste impacted biowaste treatment facilities operations, leading to improper treatment and/or disposal, mainly in cities without the necessary resources to deal with the waste increment (Filimonau, 2021).

5) The plastic demand increased, particularly for personal protection products (e.g., facemasks, wipes, and gloves) and healthcare purposes, which caused the growth of plastic waste generation (Vanapalli et al., 2021).

6) The pandemic caused volatility in secondary material prices and a decline in profits of waste-to-material companies. Recycling cooperatives and scrap brokers were also heavily impacted, mainly in poor and developing nations (Almeida et al., 2021; Zhou et al., 2021).

7) Waste logistics operations, including collection, transportation, and disposal of waste, were hindered during the pandemic outbreak, which created additional barriers for the proper waste destination (Babaee Tirkolaee \& Aydın, 2021).

8) The pandemic intensified the mismanagement of recyclable materials, particularly in developing nations, causing further economic loss and social impacts. Readers are guided to (Warmadewanthi et al., 2021) for more information. 
9) Scholars argue that the temporary interruption of selective collection and recycling and the relaxation of waste policies during the critical pandemic period may negatively affect the waste system in the post-pandemic scenario. Besides, it is worth mentioning that the pandemic has postponed recycling and plastic waste policies (Liang et al., 2021; Penteado \& Castro, 2021).

\section{Analysis}

Our society has fragilities that are exposed and intensified during emergency scenarios. Using the iceberg metaphor, waste pollution is only the tip of the iceberg (Figure 1). Therefore, oriented actions are needed to improve existing waste systems and face future pandemic-like situations.

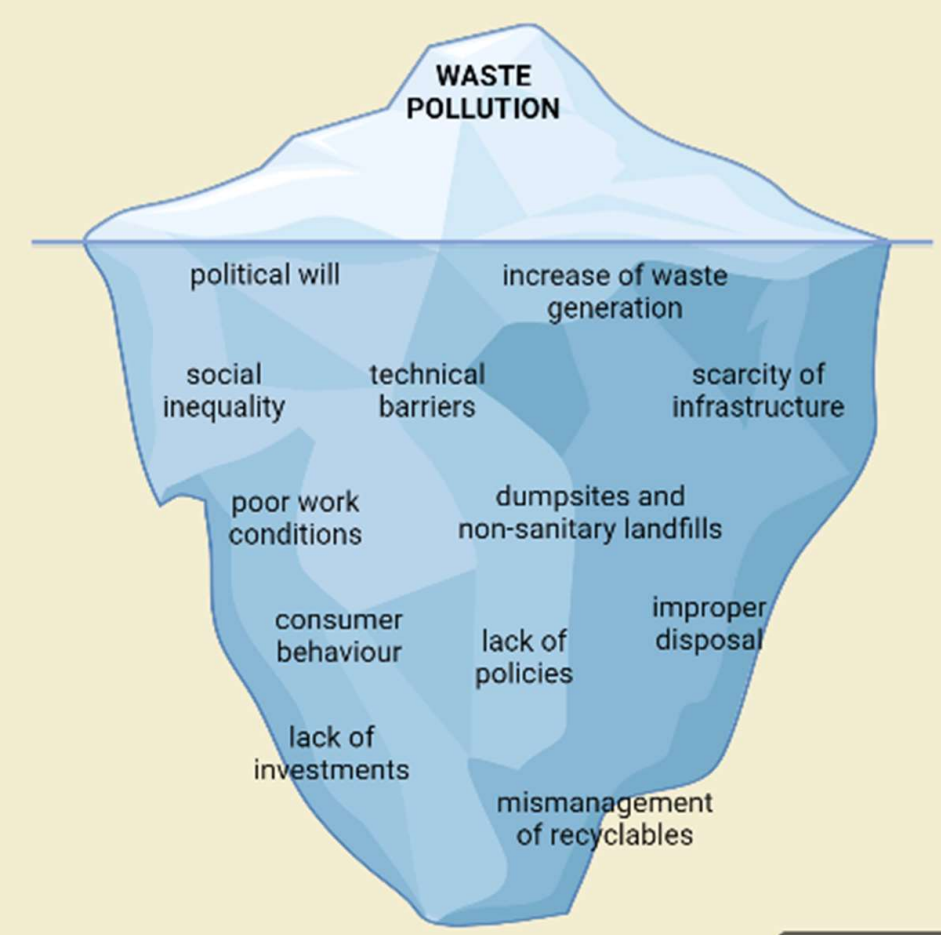

Created in BioRender.com bio

Figure 1. The iceberg analogy for the waste problem. Created in BioRender.com

\section{Recommendations}

Concerning biomedical wastes, monitor both the production and the installed capacity of treatment facilities to assess an eventual need for system expansion is pivotal to construct a more resilient waste system. Besides, the frequency of waste 
collection needs to be increased and modulated according to specific needs. Temporary alternatives for biowaste management should be utilised in unforeseen circumstances, particularly in poor and developing countries. For example, if existing biowaste plants cannot deal with the waste increment, urban incinerators, industrial furnaces, deep burial, and cement kilns should be adopted as temporary solutions (Urban \& Nakada, 2021).

Technology can play a vital role in the construction of resilient waste systems. More real-time waste data collection via satellite technology, artificial intelligence, and the internet of things for waste amount prediction and/or waste transportation optimisation can help thinkers, city stakeholders, and decision-makers to plan waste management policies strategically. Indeed, plan for potential uncertainties in advance is needed. Furthermore, the transition to automated waste systems can reduce health risks in future pandemics. Innovative waste treatment technologies and waste management models beyond existing ones and a shift to more sustainable material usage are also needed - For example, designing bio-sourced polymers and hybrid packaging materials that could enable low effort efficient recycling (Klemeš et al., 2020; Sharma et al., 2020).

On the other hand, full adoption of waste management practices requires governmental policies (e.g., specific regulations and social inclusion) and incentives (e.g., tax justice, subsides, and waste programmes), which have barely be done in emerging nations. The lack of investments to build waste facilities - landfills, composting, anaerobic digestion, and recycling plants - hinders the residues' proper final destination and constitutes a significant problem. Investments in waste sector infrastructure and environmental education - awareness campaigns, consumers/citizens guidance, diffusion of good practices for waste prevention/minimisation/reuse, and training of formal/informal workers - are required during public health emergencies and beyond.

Besides, industries must consolidate their waste management practices and get more involved in urban waste management systems. Last but not least important, selective collection and reverse logistics need improvements. Special attention to the informal recycling sector should be given in low- and - middle countries (Azevedo et al., 2019, 2021). 


\section{Conclusions}

Several studies have been published about waste management during the pandemic period, and linked to them, potential questions and future research gaps emerge. The reflective topics highlighted in the present article are not intended to be exhaustive. Still, they give us a starting point for reflecting on how we can construct a more resilient waste management system.

\section{Declaration of conflicting interests}

Ronei de Almeida declares no conflict of interest.

\section{Funding}

The author received no financial support for the research, authorship, and/or publication of this document. 


\section{References}

Agamuthu, P., \& Barasarathi, J. (2020). Clinical waste management under COVID-19 scenario in Malaysia. Waste Management \& Research: The Journal for a Sustainable Circular Economy, 5, 0734242X2095970. https://doi.org/10.1177/0734242X20959701

Almeida, R. de, Souza, R. G. de, \& Campos, J. C. (2021). Lessons and challenges for the recycling sector of Brazil from the pandemic outbreak of COVID-19. Waste Disposal \& Sustainable Energy, 0123456789. https://doi.org/https://doi.org/10.1007/s42768-021-00075-y

Azevedo, B. D., Scavarda, L. F., \& Caiado, R. G. G. (2019). Urban solid waste management in developing countries from the sustainable supply chain management perspective: A case study of Brazil's largest slum. Journal of Cleaner Production, 233, 1377-1386. https://doi.org/10.1016/j.jclepro.2019.06.162

Azevedo, B. D., Scavarda, L. F., Caiado, R. G. G., \& Fuss, M. (2021). Improving urban household solid waste management in developing countries based on the German experience. Waste Management (New York, N.Y.), 120, 772-783. https://doi.org/10.1016/j.wasman.2020.11.001

Babaee Tirkolaee, E., \& Aydın, N. S. (2021). A sustainable medical waste collection and transportation model for pandemics. Waste Management and Research, 3. https://doi.org/10.1177/0734242X211000437

Batista, M., Gusmão Caiado, R. G., Gonçalves Quelhas, O. L., Alves Lima, G. B., Filho, W. L., \& Rocha Yparraguirre, I. T. (2021). A framework for sustainable and integrated municipal solid waste management: barriers and critical factors to developing countries. Journal of Cleaner Production, 127516. https://doi.org/10.1016/j.jclepro.2021.127516

Di Maria, F., Beccaloni, E., Bonadonna, L., Cini, C., Confalonieri, E., La Rosa, G., Milana, M. R., Testai, E., \& Scaini, F. (2020). Minimization of spreading of SARS-CoV-2 via household waste produced by subjects affected by COVID-19 or in quarantine. Science of the Total Environment, 743, 140803. https://doi.org/10.1016/j.scitotenv.2020.140803

Filimonau, V. (2021). The prospects of waste management in the hospitality sector post COVID-19. Resources, Conservation and Recycling, 168(November 2020), 105272. https://doi.org/10.1016/j.resconrec.2020.105272

Ganguly, R. K., \& Chakraborty, S. K. (2021). Integrated approach in municipal solid waste management in COVID-19 pandemic: Perspectives of a developing country like India in a global scenario. Case Studies in Chemical and Environmental Engineering, 3(January), 100087. https://doi.org/10.1016/j.cscee.2021.100087

Kampf, G., Todt, D., Pfaender, S., \& Steinmann, E. (2020). Persistence of coronaviruses on inanimate surfaces and their inactivation with biocidal agents. Journal of Hospital Infection, 104(3), 246251. https://doi.org/10.1016/j.jhin.2020.01.022

Klemeš, J. J., Fan, Y. Van, Tan, R. R., \& Jiang, P. (2020). Minimising the present and future plastic waste, energy and environmental footprints related to COVID-19. Renewable and Sustainable Energy Reviews, 127, 109883. https://doi.org/10.1016/j.rser.2020.109883

Kulkarni, B. N., \& Anantharama, V. (2020). Repercussions of COVID-19 pandemic on municipal solid waste management: Challenges and opportunities. Science of the Total Environment, 743, 140693. https://doi.org/10.1016/j.scitotenv.2020.140693

Liang, Y., Song, Q., Wu, N., Li, J., Zhong, Y., \& Zeng, W. (2021). Repercussions of COVID-19 pandemic on solid waste generation and management strategies. Frontiers of Environmental Science \& Engineering, 15(6), 115. https://doi.org/10.1007/s11783-021-1407-5

Mofijur, M., Fattah, I. M. R., Alam, M. A., Islam, A. B. M. S., Ong, H. C., Rahman, S. M. A., Najafi, G., Ahmed, S. F., Uddin, M. A., \& Mahlia, T. M. I. (2021). Impact of COVID-19 on the social, economic, environmental and energy domains: Lessons learnt from a global pandemic. Sustainable Production and Consumption, 26, 343-359. https://doi.org/10.1016/j.spc.2020.10.016

Penteado, C. S. G., \& Castro, M. A. S. de. (2021). Covid-19 effects on municipal solid waste 
management: What can effectively be done in the Brazilian scenario? Resources, Conservation and Recycling, 164(August 2020), 105152. https://doi.org/10.1016/j.resconrec.2020.105152

Ramteke, S., \& Sahu, B. L. (2020). Novel coronavirus disease 2019 (COVID-19) pandemic: Considerations for the biomedical waste sector in India. Case Studies in Chemical and Environmental Engineering, 2(May), 100029. https://doi.org/10.1016/j.cscee.2020.100029

Sangkham, S. (2020). Face mask and medical waste disposal during the novel COVID-19 pandemic in Asia. Case Studies in Chemical and Environmental Engineering, 2(September), 100052. https://doi.org/10.1016/j.cscee.2020.100052

Sarkodie, S. A., \& Owusu, P. A. (2021). Impact of COVID-19 pandemic on waste management. Environment, Development and Sustainability, 23(5), 7951-7960. https://doi.org/10.1007/s10668-020-00956-y

Sharma, H. B., Vanapalli, K. R., Cheela, V. S., Ranjan, V. P., Jaglan, A. K., Dubey, B., Goel, S., \& Bhattacharya, J. (2020). Challenges, opportunities, and innovations for effective solid waste management during and post COVID-19 pandemic. Resources, Conservation and Recycling, 162(May), 105052. https://doi.org/10.1016/j.resconrec.2020.105052

Urban, R. C., \& Nakada, L. Y. K. (2021). COVID-19 pandemic: Solid waste and environmental impacts in Brazil. Science of The Total Environment, 755, 142471. https://doi.org/10.1016/j.scitotenv.2020.142471

Vanapalli, K. R., Sharma, H. B., Ranjan, V. P., Samal, B., Bhattacharya, J., Dubey, B. K., \& Goel, S. (2021). Challenges and strategies for effective plastic waste management during and post COVID-19 pandemic. Science of The Total Environment, 750, 141514. https://doi.org/10.1016/j.scitotenv.2020.141514

Warmadewanthi, I., Wulandari, D., Cahyadi, M. N., Pandebesie, E. S., Anityasari, M., Dwipayanti, N. M. U., Purnama, I. G. H., \& Nisaa, A. F. (2021). Socio-economic impacts of the COVID-19 pandemic on waste bank closed-loop system in Surabaya, Indonesia. Waste Management \& Research: The Journal for a Sustainable Circular Economy, 0734242X2110179. https://doi.org/10.1177/0734242X211017986

Yu, H., Sun, X., Solvang, W. D., \& Zhao, X. (2020). Reverse Logistics Network Design for Effective Management of Medical Waste in Epidemic Outbreak: Insights from the Coronavirus Disease 2019 (COVID-19) in Wuhan. SSRN Electronic Journal. https://doi.org/10.2139/ssrn.3538063

Zhou, C., Yang, G., Ma, S., Liu, Y., \& Zhao, Z. (2021). The impact of the COVID-19 pandemic on waste-to-energy and waste-to-material industry in China. Renewable and Sustainable Energy Reviews, 139(January), 110693. https://doi.org/10.1016/j.rser.2020.110693 